\title{
The Practice of Teaching Reading Comprehension in Secondary Schools: A Case of Debre Markos Administrative Town. May, 2019
}

\author{
Simachew Gashaye (PhD in TEFL) Dawit Dibekulu Alem (MA in TEFL) \\ College of Social Sciences and Humanities, Debre Markos University, Debre Markos, Ethiopia \\ Department of English Language and Literature, Debre Markos University, Debere markos, Ethiopia
}

\begin{abstract}
This study aimed to assess practices of teachers in teaching reading comprehension in secondary schools of Debre Markos administrative town. For this, descriptive survey design and both quantitative and qualitative data analyses approaches were employed. The samples were 254 students and 33 teachers selected using systematic random sampling. Questionnaire, interview, classroom observation and documents were data collection tools. Both descriptive (mean, SD, frequency and percentage) and inferential statistics (one sample-test) were used to analyze the quantitative data and thematic narration for qualitative. The one sample t-test value for pre-reading phase obtained from teachers $(\mathrm{M}=3.01)$, which is almost equal to expected mean $\mathrm{t}$-value $(\mathrm{t}=0.36, \mathrm{df}=32, \mathrm{p}>0.05)$ and from students $(\mathrm{M}=2.21)$ is significantly lower than expected mean value $(\mathrm{t}=103.27, \mathrm{df}=253, \mathrm{p}<0.05)$. This indicates that the implementation of pre-reading activities was not as expected. The while reading phase mean scores obtained from teachers $(\mathrm{M}=2.73),(\mathrm{t}=-7.93, \mathrm{df}=32, \mathrm{p}<0.05)$ and students $(\mathrm{M}=2.27)$ are lower than the expected mean value $(\mathrm{t}=103.27, \mathrm{df}=253, \mathrm{p}<0.05)$ indicates that the implementation of while-reading activities was not as expected. Similarly, for post reading phase, the mean score obtained from teachers $(\mathrm{M}=2.82),(\mathrm{t}=-3.76, \mathrm{df}=32$, $\mathrm{p}<0.05)$ and from students $(\mathrm{M}=2.16)$ both found lower than the expected value $(\mathrm{t}=78.34, \mathrm{df}=253, \mathrm{p}<0.05)$ implies that the implementation of post-reading activities was not as expected. The one-sample test score for the application of teaching strategies obtained from teachers $(M=3.67)$ is significantly greater than the expected mean $\mathrm{t}$-value $(\mathrm{t}=13.83, \mathrm{df}=32, \mathrm{p}<0.05)$. But the mean value $(\mathrm{M}=2.50)$ obtained from students is significantly lower than expected mean $\mathrm{t}$-value $(\mathrm{t}=91.54, \mathrm{df}=253, \mathrm{p}<0.05)$. This indicates that teachers and students react differently. Moreover, student, teachers, subject content and context related factors were found affecting teachers teaching practice significantly with some differences in between teachers and students. The qualitative data also showed that the three phases of reading comprehension were not practiced to the expected level. In addition teachers, students, the context were causal factors that hamper the practice dominantly. Thus, it is possible to recommend that trainings should be organized starting from school level to the MoE in order to improve teachers teaching capacity and to overcome the problems identified.
\end{abstract}

DOI: $10.7176 / \mathrm{JEP} / 10-22-04$

Publication date: August $31^{\text {st }} 2019$

\section{INTRODUCTION}

Reading is important among the four language skills. It is explained by different scholars based on their own views. According to Palani (2012), reading is the identification of symbols and the association of appropriate meaning with them that requires identification and comprehension. For Goodman (1998) reading is receptive and psycholinguistic process which starts with a linguistic surface representation encoded by a writer and ends with meaning constructed by the reader. Many years ago reading in English as a foreign language was perceived as a passive process (Carrell, 1998).

As to Brown (2000), English language teaching tradition has been subject to tremendous change, especially throughout the twentieth century. Perhaps more than any other discipline, this tradition has been practiced, in various adaptations, in language classrooms all around the world for centuries. Teachers are one of the key elements in any school and effective teaching is one of the key propellers for school improvement. Teacher effectiveness is generally referred to in terms of a focus on student outcomes and the teacher behaviors and classroom processes that promote better student outcomes (Ko, Sammons and Bakkum, 2016, Killen, 2006 ). Moreover, Gibbs (2002) explained that an effective teacher needs the capacity to be persistent, flexible, and innovative on new teaching approaches and be prepared in the case of failure. For Stronge, Tucker and Hindman (2004), the effective teacher has a psychological influence on the students, having a strong influence on their achievement. With great emphasis Ayalew (2009), reported that whatever curriculum change is introduced and whatever reforms are made, all will be of little or no avail without qualified and committed teachers.

Teachers who are effective in teaching reading should employ useful strategies that are helpful to develop students reading skills. At its broad sense, the goal of all reading instruction is ultimately targeted at helping readers comprehend the text (Shewa, 2017). According to Uygun (2013), effective language teaching has become a prominent issue in the field of education as there has been a great demand on learning foreign languages 
throughout the world. In the process of foreign language learning, the language teacher has a very important role on the students and their success depends on the skills of the teachers. This is also true in our country Ethiopia, the demand to get effective teachers is the natural question in every school.

It is an established fact that reading skill has a paramount importance in English as a foreign language context where students have limited access to learn the language. Huang et al, (2008) and Lien(2011), stated that reading plays important role in determining academic success or failure of learners at different levels. Reading can enhance not only language proficiency but also other content related learning, and it helps to gain understanding of the world, enabling the students to think about and react to what they read; it is because knowledge is highly dependent on how much a person reads.

As stated in education and training policy of our country Ethiopia, English is selected to be the medium of instruction for secondary and higher education (MOE, 1994). Moreover, it is also one of the subjects that students are taking starting form KG to higher levels of education. Numerous efforts have been made to improve students as well as teachers English language skills despite visible gains are not observed. Frequent trainings had been given for English language teachers, improvement programs like ELIC is designed and implemented, and English language clubs are established in schools and educational institutions. However, this has been done the proficiency of teachers in teaching the language as well as students' academic achievements in English remain low. Learners enrolled in primary schools in various regions of Ethiopia have reading difficulties and are, thus, challenged in attending their education (EGRA/Ethiopia, 2010; MoE, 2008). Furthermore, the Ethiopian Education Sector Development Program (ESDP-V) (2016) shows that a lack of basic skills in early grades prevents Ethiopian learners from learning their mother tongue, Amharic, and second language English. The problem extends to secondary and higher education levels.

A study by Habtamu (2016) revealed that teachers rarely played their roles to improve the students' reading speed and comprehension in the classroom reading due to lack of awareness. Moreover he reported that the problem related to school like less oriented to the reading skills, lack of finance, lack of awareness toward reading strategies , large number students in each class, unsuitability of seating arrangements to pair and group works and lack of access to teaching aids are factors related to teaching reading comprehension. Another study by Shewa (2017) indicated that the main impediments while practicing for reading comprehension are lack of regular practice, poor high school background knowledge, and lack of motivation, large class size and lack of teacher commitment in supporting students, loss of attention towards implied meanings and problem of using reading strategies effectively.

Dereje (2013) conducted a study on similar issue as that of this study but in different contexts. He found out that teachers have been giving less emphasis on the usefulness of efforts in promoting students' reading skills and engagement. He also reported that teachers have not understood the importance incorporating basic reading phases and related strategies. Mesfin (2008) also indicated that the practices of teaching reading in schools were traditional where current techniques and procedures of teaching and learning English as a foreign language have not been used. It has been dominated by reading aloud where pre, while and post reading activities are not implemented.

Moreover, a study conducted by Teshome (2016) aimed to investigating the way English language teachers implement the procedures described in the new course book, which was designed with communicative orientation for grade nine with particular reference to four selected government schools in Segen zone,DerasheWoreda. The result of this study indicate that there is an overlap between what the Teacher's guide suggested and what they really do in the actual classroom implementation of reading lessons. Concerning the implementation of the three most common reading strategies for teaching reading lessons, the majority of teachers claimed that they sometimes practice in the classroom.

As per the reviewed studies from the abroad and local on reading skills in particular by focusing on students' performance and practices of teachers teaching reading in general, it was possible to underscore the presence of problems of teaching reading comprehension in one way or another. Alike these researches this study focused on teachers practices of teaching reading comprehension in general but it is made to focus on identification of teachers actual practices of applying the three basic reading phases and related strategies on one hand and what factors were affecting their practice on the other hand. Because of the contexts are different (teachers, students and study area) and the issues considered are important the researcher understood that further investigations were needed to see how teachers' properly teach and apply reading phases and strategies. And the research observed and discussed with English Language teachers at the secondary schools of Deber Markos administrative town the teachers give less emphasis in teaching reading comprehension lessons and were not aware of multiple reading strategies.

Moreover, the researcher believes that there is a gap between what is suggested as effective teaching reading in the literature and the current reading instructional practices, which warrants further study in the area. To this end, this study was focused on the identification of teachers' practices and their proper application of reading phases and strategies in teaching reading comprehension in Debre Markos Administrative Town secondary schools grade 9 in focus.

Thus, the general objective of this study is assessing practices of teachers' teaching reading comprehension 
in secondary schools of Debre Markos Administration Town. To achieve the objectives, this study was designed to answer the following leading questions.

1. How often teachers' apply reading phases properly in their actual classroom teaching?

2. How do teachers' employee the basic reading comprehension strategies required of each reading does phases to teach reading comprehension?

3. What are the factors that affect teachers' not to teach reading comprehension (if there are any)?

It is hoped that the findings of the study could help teachers to aware of the existing situation and, make their efforts to improve students' reading comprehension skills by implementing appropriate reading strategies, and procedures, and reconsider the function of teaching reading comprehension strategies in EFL/ESL classes and promote students' ,reading strategy usage in general, and it might contribute to improve the process of teaching English in general and the reading comprehension in particularly.

\section{RESEARCH METHODOLOGY}

\subsection{Research Design}

Descriptive survey design and mixed data analysis approaches were employed in this study. According to Creswell (2014) explained survey design provides a quantitative or numeric description of trends, attitudes, or opinions of a population by studying a sample of that population. As the nature of the study is describing teachers' practices in teaching reading comprehension and to explore to what extent they use proper reading phase and strategies descriptive survey design is felt to be appropriate.

\subsection{Population, Samples and Sampling Techniques}

Debre Markos Administrative town has 4 secondary and preparatory schools of which two are from grade 9-10, the other one is from grade 9 to 12 and one is preparatory school from grade 11-12. The study was conducted by taking three of these schools taking grade 9 into consideration. Thus the populations of the study were all English language teachers (42) and 2540 grade $9^{\text {th }}$ students. Administrative bodies and other grade levels are neglected intentionally. The samples were taken from each of the schools proportionally. After proportionality, students in the selected grade level were selected using systematic random sampling from each learning sections. So, in this school, Grade $9^{\text {th }}$ students were holding a total of 50 sections in the three schools in which 2540 students were attending their education. Regarding to this Kumar (2006) say descriptive research typically uses large samples; it is sometimes suggested that one should select 10-20 percent of the accessible population for the sample. Therefore, by taking lists of students from each section samples $10 \%$ (254 students) were selected using systematic random sampling after sections are selected using random sampling technique (lottery method). Because, systematic random sampling is an easier and less cost method of sampling and can be conveniently used even in case of large populations (Kothari, 2004). Regarding teachers, 33 teachers were selected using random sampling. As to Kothari random sampling from a finite population refers to that method of sample selection which gives each possible sample combination an equal probability of being picked up and each item in the entire population to have an equal chance of being included in the sample. This indicates that the selection of teachers in regarding the teachers is representative.

\subsection{Data Collection Instruments}

\subsubsection{Class Room Observation}

Observation is pertinent data collection instrument to get first hand data from the exact situation. It allows the researcher to study the pedagogic process in natural setting and provides more detailed and precise evidence. Thus check list guided observation was conducted by the researcher himself and two co-observers to make it reliable, at list for 12 different classroom teaching classes 4 (four) from each of the schools particularly on reading class activities. Since observation is the systematic description of the events, behaviors, and artifacts of a social setting (Marshall \& Rossman, 1989). This was conducted by preparing observation checklist guide for the purpose of looking the actual class room practice of teachers teaching in reading comprehension. In addition to this, to get the data which was not observed by checklist filed notes were taken during observation. The checklist has three parts; items related to pre, while, post reading phases and other strategies were included. It was at getting more useful information on how effectively the sample teachers teach reading comprehension.

\subsubsection{Questionnaire}

Questionnaires are a good way to obtain information from a large number of people and/or people who may not have the time to attend an interview or take part in experiments. They enable people to take their time, think about it and come back to the questionnaire later (Marshall \&Rossman, 1989). Questionnaires' were prepared for both teachers and students containing relevant points to the study. That is, it contains four parts; the first is background information of the respondent, the second part reading phases (pre-while and post reading phases and related strategies), and the third part is teacher practice of teaching reading comprehension, and finally the challenges affecting teachers' practices of teaching reading comprehension were included. For these items were adapted from 
(Leyla and Almacioğlu, 2009; Teshome, 2016;Dereje, 2013; and Bedasa, 2013) with some modifications and some of the items were designed by the researcher based on theoretical bases of teaching reading comprehension to measure teachers' practices. A questionnaire which consists of both closed and one open ended items were design for both the sample teachers and students. All the items of the teachers and students were basically the same in terms of content although some could be worded slightly different.

\subsubsection{Interview}

Interview was one of the instruments for this study. It was conducted with selected teachers five in number). For this semi-structured interview guide was prepared basically focusing on practice of teaching reading phases and related strategies, and factors hindering their teaching practices. Interviews are particularly useful for getting the story behind a participant's experiences. According to McNamara, (1999) the interviewer can pursue in-depth information around the topic. Interviews may be useful as follow-up to certain respondents to questionnaires e.g. to further investigate their responses. And semi-structured interview is useful when there is a need to collect indepth information in a systematic manner from a number of respondents or interviewees (e.g., teachers, community leaders). Some teaching reading comprehension strategies are mainly covert behaviors that teachers may not certainly respond to that part of the questionnaire. It is believed that, therefore, better evidence could be obtained if teachers' will be invited to tell in a face to face communication about what they do in teaching reading comprehension. Hence, in order to aid the data on the type and proper teaching of reading strategies as well as phase obtained from the questionnaire.

\subsubsection{Document Analysis}

Document analysis was used as a tool to assess whether the contents of the students' text books are suitable to teach reading comprehension phase and related strategies or not an to cross check whether the teacher practical teaching is based on the text book as well as to see it if it was the factor for teachers do not practiced reading phases as well as reading strategies. Therefore, sample reading lessons that were taught during the observation lessons were analyzed by using checklist. And the checklist was designed by selecting the items which were included in the questionnaire and observation.

\subsection{Validity and Reliability of the Instruments}

The reliability and validity for the instruments was checked before the instrument distributed and hold on to the respondents.

\subsubsection{Validity of the Instruments}

Before the actual data collection process was made validity was checked (face, content and construct validity) by consulting English language teachers in Debre Markos university (their specialization is TEFL) and tools were revised accordingly (from student questionnaire English version) 6 items were revised and for teachers questionnaires 3 instructions and 7 items were made some modification based on the comments), and 3 items related to strategies were deleted. And the Amharic version also checked by Debre Markos University Amharic language teachers and there are minor modification on some contents (5 items).

\subsubsection{Reliability of the Instruments}

After all the instruments was made ready, their reliabilities were check by using pilot test in one of secondary schools in Gozamin Woreda ( Gozamin General Secondary and Preparatory school) and calculating the reliability coefficients using Crombach alpha for reading phases, other teaching strategies and factors separately and found that $0.89,0.79$ and 0.72 respectively which was acceptable. Regarding this, Crombach(1951) forwarded that commonly accepted rule for describing internal consistency using Cranach's alpha is $0.90 \leq \alpha$ is excellent, $0.80 \leq$ $\alpha<0.90$ is good, $0.70 \leq \alpha$ is acceptable $<0.80,0.60 \leq \alpha<0.70$ is questionable, $0.50 \leq \alpha<0.60$ is poor, and $\alpha<$ 0.5 is unacceptable. So, in regarding to the reading phase the items have good, reading strategies and factors were also acceptable.

\subsection{Data Collection Procedures}

In the first place to get authentic data respondents were volunteer, willing and positive. For this cooperation letter was written from the college, and the researcher explained the purpose of the study by communicating with school directors and teachers. After this happens all the instruments was made ready, proper time for data collection was arranged and problems was handled accordingly. The other thing that the researcher has been done that orientation was given for both teachers and students before they fill and respond for the questions. Moreover, a questionnaire was translated in to Amharic for the ease of understanding particularly for students. In addition to this, observation was hold on first, because if the questionnaire and or interview was conducted first, teachers might modify or use artificial teaching method based on some information on these tools on reading class of each school. So, a questionnaire comes second, interview was conducted, and finally document analysis was analyzed to triangulate the data. 


\subsection{Data Analysis Techniques}

As indicated both qualitative and quantitative techniques were employed to analyze the data collected. The quantitative data was analyzed using descriptive statistics (mean and standard deviation employed for questionnaire and frequency and percentage were for observation) and one sample t-test was employed to compare mean difference of respondents with the expected mean by using SPSS version 20.0(Statistical Package For Social Sciences). The qualitative data was analyzed using narrations.

\section{ANLYSIS AND DISCUSSION OF RESULTS}

\subsection{Demographic Data Analysis of Respondents}

Teachers and students were samples of the study. Students' sex and grade level distribution as well as teacher's sex, educational qualification and experiences are reported as follows.

Table 1 : Respondents demographics data

\begin{tabular}{|c|c|c|c|c|c|}
\hline \multirow[t]{3}{*}{ Demographic characteristics } & \multirow[t]{3}{*}{ Description } & \multicolumn{4}{|c|}{ Respondents } \\
\hline & & \multicolumn{2}{|c|}{ Students } & \multicolumn{2}{|c|}{ Teachers } \\
\hline & & $\mathrm{N}$ & $\%$ & $\mathrm{~N}$ & $\%$ \\
\hline \multirow[t]{3}{*}{ Sex } & Male & 117 & 46.06 & 21 & 63.64 \\
\hline & Female & 137 & 53.94 & 12 & 36.36 \\
\hline & Total & 254 & 100.00 & 33 & 100.00 \\
\hline \multirow[t]{2}{*}{ Educational Qualification } & First Degree & & & 28 & 84.85 \\
\hline & $2^{\text {nd }}$ Degree & & & 5 & 15.15 \\
\hline \multirow{4}{*}{ Experiences in years } & $6-10$ years & & & 2 & 6.06 \\
\hline & 11-15 years & & & 12 & 36.37 \\
\hline & $16-20$ years & & & 11 & 33.33 \\
\hline & Above 20 years & & & 8 & 24.24 \\
\hline
\end{tabular}

As indicates in table one $117(46.06 \%)$ of students were males and $137(53.94 \%)$ were females. Thus, it is possible to say students were fairly included in the sample. Regarding teachers $21(63.64 \%)$ and $12(36.36 \%)$ were males and females. Amongst these 33 teachers 21(63.64\%) and 12(36.36\%) were assigned to teach grade 9 and also $28(84.85 \%)$ and $5(15.15 \%)$ were first degree and second degree holders in that order. In relation to their experiences, $2(6.06 \%), 12(36.37 \%), 11(33.33 \%)$ and $8(24.24 \%)$ were reported as they have 6-10 years, $11-15$, 16-20 and above 20 years of experiences respectively.

From this it is possible to infer that the samples included were appropriate to collect pertinent data for the intended purpose.

\subsection{Quantitative Data Analyses: Data Collected Using Questionnaire}

In this part of the analysis data collected through questionnaires are analyzed. In the questionnaire used to collect data, items related to pre, while and post reading activities, other teaching reading comprehension strategies and factors that may affect the teaching and learning process were responded by both teachers and students. The responses of both teachers and students organized and filled in to SPSS to calculate one sample t- test valves after an average response is calculated for each of the items to make the interpretation of the results focused on specific reading phases, practices and factors of reading rather than piecemeal activities in which 70 and 60 items for teachers and students are included. Thus, in the following part data collected using questionnaire are analyzed and reported.

\subsubsection{Teachers' Practices in Teaching Reading Phases: Teachers' Responses}

\section{A. Pre-reading Phase Data Analysis}

To assess the implementation of pre reading activities 20 items (see appendix B) and 8 items (see appendix A) were prepared for teachers and students' respectively and the responses organized and average values for each of the items were calculated. By taking the averages one sample t-test is processed using SPSS software and the obtained result is reported as follows.

Table 2 Pre reading one sample t-test results for teachers and students Response

\begin{tabular}{|c|c|c|c|c|c|c|c|c|}
\hline \multirow[t]{2}{*}{ Reading phase } & \multirow[t]{2}{*}{ Respondent } & \multicolumn{7}{|c|}{$\mathrm{t}$-value $=3$} \\
\hline & & $\mathrm{N}$ & Mean & $\mathrm{SD}$ & $\mathrm{t}$ & $\mathrm{df}$ & Sig. (2-tailed) & Mean Difference \\
\hline \multirow[t]{2}{*}{ Pre-reading } & Teachers & 33 & 3.01 & .21 & .36 & 32 & .720 & .013 \\
\hline & Student & 254 & 2.21 & .34 & 103.27 & 253 & .000 & -0.79 \\
\hline
\end{tabular}

As indicates in table 3 one sample t-test was run to see whether there is a difference between the expected mean $(\mathrm{t}=3)$ with the calculated mean value for pre reading activities. The one sample test value of the implementation of pre-reading activities mean score obtained from teachers $(\mathrm{M}=3.01)$ is almost equal to expected mean $\mathrm{t}$-value $(\mathrm{t}=0.36, \mathrm{df}=32, \mathrm{p}=0.720)$ which is not significant. This shows that the implementation of pre-reading activities was 
approaching to the expected level. From this it is possible to conclude that the implementation of pre-reading activities was almost performed at the average level based on teachers' responses. And the one sample test value of the implementation of pre-reading activities mean score obtained from students $(\mathrm{M}=2.21)$ has a mean difference $(0.79)$ below the expected $t$-value and it is significantly lower than expected mean $t$-value $(t=103.27, d f=253$, $\mathrm{p}<0.05)$. This result contradicts with teachers. Thus, this indicates that the teachers' were not properly practiced pre reading phase and related strategies.

\section{B. While Reading Phase Data Analysis}

To assess the implementation of while reading activities 16 items (see appendix B) and 10 items (see appendix A) were prepared for teachers and students respectively and the responses obtained are taken to calculate the average score. By taking the averages one sample t-test is processed using SPSS software and the obtained result is reported as follows.

Table 1:While- reading one sample t-test result for teachers' responses

\begin{tabular}{|c|c|c|c|c|c|c|c|c|}
\hline \multirow{2}{*}{$\begin{array}{l}\text { Reading } \\
\text { phase }\end{array}$} & Respondent & \multicolumn{9}{|c|}{ t-value =3 } \\
\cline { 3 - 9 } & & $\mathrm{N}$ & Mean & SD & $\mathrm{t}$ & $\mathrm{df}$ & Sig. (2-tailed) & Mean Difference \\
\hline $\begin{array}{c}\text { While- } \\
\text { reading }\end{array}$ & Teacher & 33 & 2.73 & .19 & -7.93 & 32 & .000 & -.27 \\
\cline { 2 - 9 } & Student & 254 & 2.27 & .39 & 90.86 & 253 & .000 & -0.73 \\
\hline
\end{tabular}

As indicates in table 4 one sample t-test was run to see whether there is a significant difference between the expected mean $(\mathrm{t}=3)$ with the actual calculated mean value for while reading activities. The one sample test value of the implementation of while-reading activities mean score obtained from teachers $(\mathrm{M}=2.73)$ is significantly lower than the expected mean value $(\mathrm{t}=-7.93, \mathrm{df}=32, \mathrm{p}<0.05)$. This shows that the implementation of while reading activities was below the expected performance level.

The mean value $(M=2.27)$ obtained from students has a mean difference $(0.73)$ below the expected t-value which is almost similar to that of teachers but significantly lower. That is the one sample test value of the implementation of while-reading activities mean score obtained from students $(\mathrm{M}=2.27)$ is significantly lower than expected mean $\mathrm{t}$-value $(\mathrm{t}=103.27, \mathrm{df}=253, \mathrm{p}<0.05)$. Thus, the result obtained from both teachers and students indicate that the implementation of while-reading activities was not as expected and below the expected level of performance. It is obvious while reading contains the main parts of the lesson that students should learn from however the practice of teachers in the implementation of related activities required of this phase is found poorly practiced.

\section{Post-reading Phases Data Analysis}

To assess the implementation of post reading activities 6 items (see appendix B) and 7 items (see appendix A) for were prepared teachers and student respectively and the responses obtained are taken to calculate the average score. By taking the averages one sample t-test is processed using SPSS software and the obtained result is reported as follows.

Table 2 Post- reading one sample t-test result for teachers' response

\begin{tabular}{|c|c|c|c|c|c|c|c|c|}
\hline \multirow{2}{*}{$\begin{array}{c}\text { Reading } \\
\text { phase }\end{array}$} & Respondent & \multicolumn{9}{|c|}{ t-value =3 } & $\begin{array}{c}\text { Mean } \\
\text { Difference }\end{array}$ \\
\cline { 3 - 9 } & & $\mathrm{N}$ & Mean & $\mathrm{SD}$ & $\mathrm{t}$ & $\mathrm{df}$ & $\begin{array}{c}\text { Sig. (2- } \\
\text { tailed) }\end{array}$ & -.18 \\
\hline \multirow{2}{*}{ Post reading } & Teacher & 33 & 2.82 & .28 & -3.76 & 32 & .001 & .000 \\
\cline { 2 - 9 }
\end{tabular}

As indicates in table 5 one sample t-test was run to see whether there is a difference between the expected mean $(t=3)$ with the calculated mean value for post reading activities. The one sample test value of the implementation of post-reading activities mean score obtained from teachers $(\mathrm{M}=2.82)$ is lower than the expected mean value $(\mathrm{t}=-3.76, \mathrm{df}=32, \mathrm{p}<0.05)$. This shows that the implementation of post reading activities was significantly lower than the expected performance level.

The mean value $(M=2.16)$ obtained from students has a mean difference $(0.84)$ below the expected t-value which is lower than that of teachers. That is the one sample test value of the implementation of post-reading activities mean score obtained from students $(\mathrm{M}=2.16)$ is significantly lower than expected mean $\mathrm{t}$-value $(\mathrm{t}=78.34$, $\mathrm{df}=253, \mathrm{p}<0.05)$.

From the above result it is possible to explain that the implementation of post-reading activities was not as expected with small difference in between the teachers and students. Here it is possible conclude that post reading activities were not performed in the expected level based on the responses of both teachers and students.

As stated above teachers were interviewed to respond whether they were using three phases of reading and important activities that should be included in each of the phases during their class room instruction or not. In this regard most of the interviews responded that they tried to teach reading comprehension but they didn't use the three phase strategies effectively. In general it understood that they were not properly employ teaching reading phases as well as reading strategies. But few strategies were practiced by teachers especially at the while reading 
phase.

As one of the interviewee explained (coded as T1):

"Most of the time, intentionally or not I tried to introduce my lesson through explaining about the passage or sometimes asking open ended questions to students. After introduction I order students to read the passage and imitate them to ask questions that are not clear for them. Finally, I always give a comprehension questions from the text as homework or class work. But I didn't consider phases that should be followed in teaching reading passages."

Another female teacher interviewee ( T2) repeated it with different expression. She stated as:

"Whatever a rule or not it seems usual to introduce the lesson at the beginning of the class and checking students homework provided previously. I usually ask questions related to the reading passage but I didn't focus on word meanings. Sometimes I jump to the grammar questions when I see students are bored of the passage."

\subsubsection{Teachers' Practices of Using Strategies in Teaching Reading Comprehension: Teachers' Responses}

There are well known strategies to be used by teachers in teaching reading comprehension. amongst these strategies (10 in number) (see appendix B and appendix A). namely visualizing/mental images, summarizing inferring, questioning, making connections, predicting, self-monitoring and clarifying were selected and given to both teachers and students to rate them to what extent these strategies were practically used in the actual teaching and learning process of reading comprehension. The responses obtained from teachers and students are analyzed and reported separately as follows.

The responses obtained from teachers are organized and changed in to average results as that of the reading phase's items and one sample t-test is used to compare the results with the expected mean score. The result is presented as follows.

Table 3 Practices of using teaching strategies one sample t-test result for teacher responses

\begin{tabular}{|c|c|c|c|c|c|c|c|c|}
\hline Strategies & Respondent & \multicolumn{9}{|c|}{$\mathrm{t}$-value =3 } \\
\cline { 3 - 9 } & & $\mathrm{N}$ & Mean & $\mathrm{SD}$ & $\mathrm{t}$ & $\mathrm{df}$ & $\begin{array}{c}\text { Sig. }(2- \\
\text { tailed) }\end{array}$ & $\begin{array}{c}\text { Mean } \\
\text { Difference }\end{array}$ \\
\hline $\begin{array}{c}\text { Practices of } \\
\text { teaching readings } \\
\text { Strategies }\end{array}$ & Teachers & 33 & 3.67 & .28 & 13.83 & 32 & .000 & .67 \\
\cline { 2 - 9 } & Student & 254 & 2.50 & .44 & 91.54 & 253 & .000 & -0.50 \\
\hline
\end{tabular}

As indicates in table 9 one sample t-test was run to see whether there is a difference between the expected mean $(t=3)$ with the calculated mean value for actual practices to use different strategies to teach reading comprehensions effectively. The one sample test score obtained from teachers $(\mathrm{M}=3.67)$ is significantly greater than the expected mean $\mathrm{t}$-value $(\mathrm{t}=13.83, \mathrm{df}=32, \mathrm{p}<0.05)$. This shows that teaching strategies were usually used properly.

The mean value $(\mathrm{M}=2.50)$ obtained from students has a mean difference $(0.50)$ below the expected $t$-value which contradicts with teachers. That is the one sample test value implies reading teaching strategies were used rarely against that of teachers which is significantly lower than expected mean $t$-value $(\mathrm{t}=91.54, \mathrm{df}=253, \mathrm{p}<0.05)$.

This indicates that teachers and students react differently to the practice of using effective teaching strategies, teachers responded as they practiced and used the give strategies whereas students responded as teachers were not used these strategies to the expected level. This might be debating to conclude to what extent teachers has been employed the strategies in the classroom effectively.

4.3.5Factors Affecting Teachers' Practices of Teaching Reading Comprehension: Teachers' and students Responses

There are many barriers that hinder teachers teaching and students learning in the process instructing reading lessons and others as well. Amongst these factors related to students, teachers, the subject matter and context are used. The responses collected are organized and changed in to average results as that of the former and one sample t-test is used to compare the results with the expected mean score. The result is presented as follows.

\section{A. Student Related Factors}

In teaching and learning process of reading comprehension the role of students is considered as one factor. So, to see the extent of this factor, teachers and students were asked 5 (five) items (see appendix A and B). However students are different as compared to each other there are some behaviors they can share in common. In this study some expected points which were related to students as hindering factors to teach/ or learn reading comprehension were used collect data from teachers. The results obtained are reported following similar pattern with the previous discussion. 
Table 4 Student related factors on reading one sample t-test result for teachers' response

\begin{tabular}{|l|l|l|l|l|l|l|l|l|}
\hline \multirow{2}{*}{ Factors } & \multirow{2}{*}{$\begin{array}{l}\text { Respond } \\
\text { ent }\end{array}$} & \multicolumn{7}{|c|}{ t-value =3 } \\
\cline { 3 - 9 } & & $\mathrm{N}$ & Mean & $\mathrm{SD}$ & $\mathrm{t}$ & $\mathrm{df}$ & $\begin{array}{l}\text { Sig. (2- } \\
\text { tailed) }\end{array}$ & $\begin{array}{l}\text { Mean } \\
\text { Difference }\end{array}$ \\
\hline $\begin{array}{l}\text { Student related } \\
\text { factors }\end{array}$ & Teacher & 33 & 4.19 & .32 & 21.59 & 32 & .000 & 1.19 \\
\cline { 2 - 9 } & Student & 254 & 3.18 & .59 & 85.13 & 253 & .000 & 0.18 \\
\hline
\end{tabular}

As indicates in table 11 one sample t-test was run to see whether there is a difference between the expected mean $(\mathrm{t}=3)$ with the actual calculated mean value for students related factors in teaching reading comprehension. The one sample test value for students related factors mean score obtained from teachers $(\mathrm{M}=4.19)$ is significantly greater than expected mean $\mathrm{t}$-value $(\mathrm{t}=21.59, \mathrm{df}=32, \mathrm{p}<0.05)$. This shows that students related factors were highly influences to teach reading comprehension properly. This indicates both teachers responded as factors related to students are highly influence teaching/ reading comprehension.

The mean value $(M=3.18)$ obtained from students has a mean difference $(0.18)$ above the expected t-value. That is the one sample test value of the students related factors mean score obtained from students $(\mathrm{M}=3.18)$ is significantly greater than expected mean $\mathrm{t}$-value $(\mathrm{t}=85.13, \mathrm{df}=253, \mathrm{p}<0.05)$.

This indicates students responded as factors related to students influence teaching/ reading comprehension. That is, students themselves were influencing the teaching and learning in reading comprehension, but when compared with teachers' response; it is smaller nearer to average. Thus, from this it is possible to conclude that students' related factors (confidence, language, vocabulary, and interest and unfamiliarity problem) were the factors which affect the teachers no to teach reading comprehension properly.

Regarding to what extent teachers were using practical strategies like asking and answering questions, monitoring comprehension, meta cognition, recognizing story structure, and multiple strategies interviewees reacted differently.

Interviewee (T4) explained it as:

"Asking questions is mandatory in every English lessons including reading comprehensions. I used to ask questions in every class I have. But I am not able to use multiple strategies, meta cognition and the like. To tell you frankly the classes I conducted were almost the same."

Interviewee (T5) adds the following.

"It is usual to ask questions however most of the students are not volunteer to take part in the question and answer method of teaching. Some passages are not organized in the way to teach reading comprehension effectively"

As indicated data were also collected using classroom observation check list. The classroom observation check list was made to contain the three reading phases and application of selected teaching strategies. In addition, the classroom observations were conducted in each of the selected schools for 12 classes as indicated above. The observed lessons are also carefully selected to see the intended practices (the lessons chosen are attached in the appendix). To this end the observation results related to the three phases of reading activities is reported as follows.

As can be seen in the check list items 1-6 refer to the pre-reading phase, 7-16 were on while reading and 1721 were related to post reading phases and the last five items of performance other reading comprehension. Regarding the lessons observed: reading lesson topics Media in Ethiopia, success in fashion world, when I won the lottery were three of the 12 passages (all the lists are attached in appendix).

What commonly observed in all of the lessons the classes were started by introducing the lesson topic and its purpose. But one of the observed teachers didn't introduce his lesson to the expected level in the first observation, instead he started his teaching by checking whether students did their homework or not. As indicated the completed check list most of the expected activities to perform at each of the reading phases were not addressed very well. There was inconsistent practice of teachers to follow the procedures necessarily important to achieve reading objectives. Similar observations are recorded for all teachers and each of the lessons observed. Most of the teachers (possibility all) were not able to follow the procedures and to use effective reading strategies and governed by the usually conventional teaching method which was not changed in every lesson.

\section{A. Teacher Related Factors}

Teachers are also factors who affect students learning either positively or negatively. Thus, teachers and students were asked 4(four) items (see appendix A and B) to know to what extent they were influencing the teaching learning of reading comprehension. The results obtained are presented as follows.

Table 5 Teacher related factors on reading one sample t-test result for teachers' response

\begin{tabular}{|c|c|c|c|c|c|c|c|c|}
\hline \multirow{2}{*}{ Factors } & Respondent & \multicolumn{9}{|c|}{$\mathrm{t}$-value =3 } & $\begin{array}{c}\text { Mean } \\
\text { Difference }\end{array}$ \\
\cline { 3 - 9 } & & $\mathrm{N}$ & Mean & $\mathrm{SD}$ & $\mathrm{t}$ & $\mathrm{df}$ & $\begin{array}{c}\text { Sig. (2- } \\
\text { tailed) }\end{array}$ & -.83 \\
\hline $\begin{array}{c}\text { Teacher related } \\
\text { factor }\end{array}$ & Teachers & 33 & 2.17 & .56 & -8.58 & 32 & .000 & .000 \\
\cline { 2 - 9 }
\end{tabular}

As indicates in table 12 one sample t-test was run to see whether there is a difference between the expected 
mean $(\mathrm{t}=3)$ with the actual calculated mean value for teachers related factors in teaching reading comprehension. The one sample test value for teachers related factors mean score obtained from teachers $(\mathrm{M}=2.17)$ is significantly less than expected mean $\mathrm{t}$-value $(\mathrm{t}=-8.58, \mathrm{df}=32, \mathrm{p}<0.05)$. This shows that teachers related factors have low influences in teaching reading comprehension effectively. This indicates teachers responded as they were not themselves as factors influencing the teaching and learning process.

The mean value $(M=3.11)$ obtained from students has a mean difference $(0.11)$ above the expected t-value. That is the one sample test value of the teachers related factors mean score obtained from students $(\mathrm{M}=3.11)$ is significantly greater than expected mean $\mathrm{t}$-value $(\mathrm{t}=73.02, \mathrm{df}=253, \mathrm{p}<0.05)$.

This indicates teachers and students responded differently for factors related to teachers. Probably it is possible to say teachers considered themselves as they were not factors to influence teaching reading comprehension whereas students responded the reverse.

\section{Subject Content Related Factors}

The contents included in the text books may also influence students learning reading comprehension. For this, 5 (Five) (see appendix A and B) items were prepared and responded by teachers and students and the result is reported as follows.

Table 6 Subject content related factors reading one sample t-test result for teachers' response

\begin{tabular}{|l|l|l|l|l|l|l|l|c|}
\hline Factors & Respondent & \multicolumn{6}{|c|}{ t-value =3 } \\
\cline { 3 - 9 } & & $\mathrm{N}$ & Mean & $\mathrm{SD}$ & $\mathrm{t}$ & $\mathrm{df}$ & $\begin{array}{l}\text { Sig. (2- } \\
\text { tailed) }\end{array}$ & Mean Difference \\
\hline $\begin{array}{l}\text { Content/ subject } \\
\text { related factors }\end{array}$ & Teacher & 33 & 3.05 & .35 & .90 & 32 & .374 & .054 \\
\cline { 2 - 9 } & Student & 254 & 3.12 & .68 & 73.17 & 253 & .000 & 0.12 \\
\hline
\end{tabular}

As indicates in table 13 one sample t-test was run to see whether there is a difference between the expected mean $(\mathrm{t}=3)$ with the actual calculated mean value for subject content related factors in teaching reading comprehension. The one sample test value for subject content related factors mean score obtained from teachers $(\mathrm{M}=3.05)$ is almost equal to expected mean $\mathrm{t}$-value $(\mathrm{t}=0.90, \mathrm{df}=32, \mathrm{p}>0.05)$. This shows that subject content related factors have moderate influences in teaching reading comprehension effectively. This indicates that the teachers responded as factors related to subject content moderately influence teaching reading comprehension.

The mean value $(M=3.12)$ obtained from students has a mean difference $(0.12)$ which is almost equal to the expected $t$-value and that of teachers responses. That is the one sample test value of the subject content related factors mean score obtained from students $(\mathrm{M}=3.12)$ is nearer to expected mean $\mathrm{t}$-value $(\mathrm{t}=75.17, \mathrm{df}=253, \mathrm{p}<0.05)$. This indicates that both teachers and students responded as factors related to subject content moderately influence teaching reading comprehension.

\section{Context Related Factors}

The other factor considered in this study was context in which the teaching learning process is going on. As that of the other factors responses were collected to know the level of its influence and 4 (four) items (see appendix A and B) were asked for teachers and student. Thus the results obtained from teachers are reported in the following manner.

Table 7 Context related factors on reading on sample t-test result for teachers' response

\begin{tabular}{|c|c|c|c|c|c|c|c|c|}
\hline \multirow{2}{*}{ Factors } & \multirow{2}{*}{$\begin{array}{c}\text { Respond } \\
\text { ent }\end{array}$} & \multicolumn{7}{|c|}{$\mathrm{t}$-value $=3$} \\
\hline & & $\mathrm{N}$ & Mean & SD & $\mathrm{t}$ & $\mathrm{df}$ & $\begin{array}{l}\text { Sig. (2- } \\
\text { tailed) }\end{array}$ & $\begin{array}{c}\text { Mean } \\
\text { Difference }\end{array}$ \\
\hline \multirow{2}{*}{$\begin{array}{c}\text { Context related } \\
\text { factors }\end{array}$} & Teacher & 33 & 3.32 & .29 & 6.34 & 32 & .000 & .32 \\
\hline & Student & 254 & 3.18 & .51 & 99.36 & 253 & .000 & 0.18 \\
\hline
\end{tabular}

As indicates in table 14 one sample t-test was run to see whether there is a difference between the expected mean $(\mathrm{t}=3)$ with the actual calculated mean value for context related factors in teaching reading comprehension. The one sample test value for context related factors mean score obtained from teachers $(\mathrm{M}=4.32)$ is significantly greater than expected mean $\mathrm{t}$-value $(\mathrm{t}=6.34, \mathrm{df}=32, \mathrm{p}<0.05)$. This shows that context related factors were highly influences teaching reading comprehension effectively. This indicates that teachers responded that factors related to contexts are highly influence teaching reading comprehension.

The mean value $(M=3.18)$ obtained from students has a mean difference $(0.18)$ above the expected t-value. That is the one sample test value of the context related factors mean score obtained from students $(\mathrm{M}=3.18)$ is significantly greater than expected mean $\mathrm{t}$-value $(\mathrm{t}=99.36, \mathrm{df}=253, \mathrm{p}<0.05)$.

This indicates that both teachers and students responded as factors related to contexts are highly influence teaching reading comprehension. The classroom arrangement, large class-size, time allotted for a period and shortage of resources were considered as contextual factors affecting teaching reading comprehension. Thus, these factors were influencing to teach reading comprehension properly.

In this regard similar responses were obtained and one of the interviewee responses is reported as follows ( T3). "Teaching reading comprehension is influenced by a number of factors. The big problem related to students. 
Students are not well prepared, motivated, and willing to attend their class actively. The text book is also big and huge page to cover all the contents on time as a result I obliged to be fast rather than teaching each of the contents. In addition, there are a lot of interruption times because of different reasons which hamper the teaching and learning process. Personally, I feel some teachers are not capable enough to teach as needed."

In addition to the above stated data results the researcher wanted to deduce the problems or factors influencing the teaching and learning of reading comprehension. From the observations made besides recording the application of the reading phases and usage of basic reading strategies problems were observed influencing the teaching learning process. Amongst these problems, teacher and student related factors were dominant. Teachers were lecture oriented rather than using newly developed strategies. Students were passive listeners except very few participants. Furthermore, the context like classroom arrangement, time allotted for the subject, lack of teaching labs and aids are some to list.

Finally, document analyses were conducted particularly to check how the lessons (passages) were designed. The passages taken for the purpose were similar to the classroom room observation thereby a match or a mismatch can be observed if the passages are lack of allowing to use phases of reading and reading strategies. To mention some: the media in Ethiopia and three African countries are examples. In the following part of the analysis six passages are analyzed as per the requirements in relation to the three phases of reading and expected teaching strategies

\subsubsection{Document (Text Book Content) Analysis}

Finally, document analyses were conducted particularly to check how the lessons (passages) were designed. The passages taken for the purpose were similar to the classroom room observation thereby a match or a mismatch can be observed if the passages are lack of allowing to use phases of reading and reading strategies and to look whether it was the factor which affect the practice of teachers' in teaching reading comprehension. To mention some: the media in Ethiopia, cities of the future, three African countries, and Poem Yaa, the Adowa Dancer are sample reviewed examples. In the following part of the analysis four passages are analyzed as per the requirements in relation to the three phases of reading and expected teaching strategies.

\section{Unit Six: Media, TV and Radio: The media in Ethiopia}

One of the reading lessons observed entitled as "the media in Ethiopia". When we look at this text the passage lacks pre-reading activities and it begins with while reading activities by asking a question "Read the following text with your partner; discuss any words that you do not understand." This shows the passage doesn't encourage teach pre -reading activities. But the question "Work with your partner to answer the following questions about the text" may initiate both teachers and students to work on while reading activities. In this case the students are required to answering different comprehension, skimming, and scanning questions.

The last activity of this section says "Find out what the following words from the text mean and use them in sentences". This activity encourages the student to know the meaning of unknown words contextually as well as predicting their meaning. Therefore, this passage comprises reading comprehension strategies like, scanning for specific information, skimming for the general idea of the text, guessing the meaning of unknown words, guessing/predict the meaning of unknown words. As a result, it can be safely to conclude the section is suitable to teach the while reading phase and related strategies. But the post reading phase and related strategies are not including on the topic but it asks on the other section.

\section{Unit Seven: Cities of the future}

The other reading lesson is taken from unit seven which was observed at Menkorer secondary school. At the beginning of this reading passage it asks "Discuss in your group what you think life will be like in a hundred years' time and list your suggestions." This question is a pre reading question which helps to know students understanding, background information, to predict about the reading passage and relate it with their experience. Next to this question the other point raised "Read the following passage" that leads to while reading activities to help the students to know specific and general information of the text but it lacks post reading activities.

In addition the question "Compare your predictions with the text. Can you add any other suggestions?" help the student to engage them in some follow-up activities, to write or speak their suggestion. And in the end "Work in pairs to find the key content words in the passage and list them, then re-tell it using these words as prompts." All these tasks help them to speak out their understanding by letting them to extract different word from the passage. Thus, passage is organized in the way to teach reading comprehension following the three steps however the practice of teachers in applying the three phases and basic strategies of teaching seems weak and inconsistent which varies from teacher to teacher.

\section{Unit Eight: Three African countries}

In this selected reading text, pre-reading phase and related strategies seems introduced by asking"What are the names of the places represented by numbers on the map?" This question helps to know students background, to relate the text/topic to their experience, to clarify objectives of the text(reading passage), and to predict what the text is about. But when we look the question "In your groups, read about one of the following African countries: Tanzania, Uganda and Kenya, Make notes of the main points and complete a chart with the following headings" 
which enables to address while reading while but few activities to accomplish it effectively.

In addition, the question, "Share your information about your chosen country with another group, Ask and answer questions with that group about your respective countries" enables to address post reading activities. If this question addressed as needed it can help the students to develop visualizing what they read, and summarize the text (written or oral). Thus, it indicates that this selected passage includes different strategies but it lacks comprehension questions as well as vocabulary activities.

\section{Unit Nine: Poem Yaa, the Adowa Dancer}

Here in the poem introduces the students "Adowa is the name of a Ghanaian dance. The poem describes that a sound picture in which the movements of the dance are described. It asks to "Read the poem and answer the questions about it." This is not pre-reading question rather it instructs the student to read the poem. So, it lacks pre-reading phases and related strategies. The second question: "How is the rhythm of the dance suggested?" these questions help the students to enhance students understanding what they read. Moreover, "Describe a dance that you are familiar with, either in poetry or in prose, so that the reader (or listener) feels that he / she can hear the music and join in the dance." This task help them visualizing what they read. Thus, this implies that this poem tried to incorporate different strategies but it lacks pre reading as well as while reading activities are not efficient. To reflect on the contents of the text in relation to addressing the pre, while and post reading activities, a researcher wanted to report that most of the contents discussed above and others included in the students text try to guide teachers to apply different teaching strategies particularly the four language skills (speaking, reading, writing, listening and grammatical aspects) are well organized in the book. As to the researcher point of view both teachers and students are not in normal way of using the lesson objectives as expected. However, the text specifically allows teachers and students to apply teaching strategies in a standardized manner teachers shall reorganize and formalize the reading exercises given following the reading phases.

\subsection{Discussion of the Results}

In the following part the results obtained are discussed supporting with related literatures from different sources. The discussion focuses on the basic results of questionnaires, interview items, classroom observation and document analysis. It is organized as discussion on phases of reading comprehension, strategies of reading comprehension followed by factors affecting teaching reading comprehension.

\subsubsection{Teachers' Practices of Applying Reading Phases}

One of the specific objectives of the study was assessing the implementations of the three phases teaching reading comprehension. For this, questionnaires, interview, classroom observation and content analysis have been conducted and the results obtained are reported as follows.

The implementation of pre- reading activities was assessed using items related with it. The one sample test mean score obtained from teachers $(\mathrm{M}=3.01)$ is almost equal to the expected mean $\mathrm{t}$-value whereas the mean value obtained from students $(\mathrm{M}=2.21)$ is significantly lower than the expected mean $\mathrm{t}$-value which contradicts with teachers. So, this indicates that the implementation of pre-reading activities was almost performed at the average level based on teachers' responses but which is not performed properly as per students' responses. The result obtained from classroom observation and filed notes from observations also indicated that teachers were not practiced properly pre-reading phase. It revealed that teachers were rarely introducing the purposes of the reading passage. The researcher observed from the actual classroom observations that teachers write the topic of the passage on the blackboard and instruct the students to silent reading followed by detail explanation of new words (rarely observed) in the reading passage but it was not performed by most of the teachers in all of their classes.

Moreover, students were not also observed to exercise this phase properly. Similarly, the result obtained from the interviewee showed that most of the teachers were not usually practiced pre- reading activity but as usual they were tried to introduce the lesson through explaining about the passage or sometimes asking open ended questions to students. Content analyses were also made to check whether the text book contains pre reading phase activities or not. Thus, in the text book pre-reading tasks are included but not in sufficient and presented validway.

Furthermore, Williams (1984) also added introducing and feeling interest in the topic, motivating learners by giving a reason for reading and to provide some language preparation for the text. It is a stage where what is called schemata knowledge could be made use of one of the major responses to increasing insights about the role of schematic knowledge in reading has been focus in current reading methodology on a pre-reading stage (Hedge 2000:192)

Similarly, Bedasa's (2013) findings revealed that pre-reading activities are not properly being implemented in ELF classrooms and there is inconsistency between what teachers believe and what they practice in classrooms and pre-reading activities were not playing their roles properly at pre-reading phase. This is also support finding of the current study which means that the teachers were not practiced pre reading activities properly and efficiently.

As that of the pre reading phase, the while reading phase was assessed against specific items planned to test the implementation. The one sample test value of the implementation of while-reading activities mean score obtained from teachers $(M=2.73)$ is lower than the expected mean value. Similarly, the mean value $(M=2.27)$ 
obtained from students has below the expected t-value which is almost similar to that of teachers but it is lower. So, this result indicates that the implementation of while reading activities was below the expected performance level. Similarly, the interview result indicated that however teachers were responsible to teach this stage properly to enable students to comprehend the passage they didn't focus on different strategies of while reading phase. From the results of classroom observation and filed notes it was also possible to ensure that some of the teachers were tried to practice skimming and scanning while they were teaching but there was some gaps in applying multiple strategies. The implementation of while-reading activities was not as expected. It is obvious that while reading contains the main parts of the lesson that students should learn from however the practice of teachers in the implementation of related activities required of this phase is found poorly practiced during class room observation. In addition to this document analysis revealed that the text book is carefully designed by considering while reading phase however teachers were not used and practiced it properly as per the grade level and syllabus need.

In connection to this, Teshome (2016) there is a match/mismatch between the prescribed procedures in the new Teacher's guide and English language teachers' actual implementation while teaching reading lessons and there is an overlap between what the Teacher's guide suggested and what they really do in the actual classroom implementation of reading lessons. Supporting this idea Anderson, et.al. (1985), explained the teacher may remind students to use comprehension strategies as they read and to monitor their understanding, ask questions that keep students on track and focus their attention on main ideas and important points in the text. Even though while reading strategies are the basic and essential part of teaching reading skills the teachers were failed to teach while reading phase and strategies without forgetting the efforts made by some of the teachers. But, the result obtained from students were significantly indicates that the teachers were not properly and efficiently by employing multiple strategies mentioned by the scholars.

Regarding the implementation of post reading phase and related strategies similar procedure was used as that of the former phases. The one sample test value of the implementation of post-reading activities mean score obtained from teachers $(M=2.82)$ is lower than the expected mean value. Similarly, the mean value $(M=2.16)$ obtained from students is lower than that of teachers. So, this shows that the implementation of post reading activities was significantly lower than the expected performance level and were not performed in the expected level based. The interview result also indicates that teachers were not properly performed post reading activities. The result obtained from classroom observation and filed notes depicted that teachers were not asking to summarize the reading passage in written form and there is inconsistency of performances among observed teachers in practicing post reading phase. Even though, this phase is essential to the students, teachers were not properly practice all the strategies in the classroom. But the analyzed passages seems good in including post reading phase activities but it is limited to address as needed.

On the contrary to this result, the literature suggested that the teachers need to apply pre reading phases and related strategies. Among these, Hedge (2000) states that a wider range of activities focusing either on the content of the text can be under taken, for example, debate, role-play, reading of contrasting texts, or focusing on its language (i.e., bottom-up processing). In addition to this, post reading exercises take students beyond the particular reading text in one of two ways: by transferring reading skills to other texts or by integrating reading skills with other language skills (Phillips, 1985). Even though, the above scholars were mentioned that the importance of post reading in teaching reading comprehension, the result indicates that the teachers were failed to practice the students.

Generally, regarding to the practices of teachers in teaching reading phases the result of this study showed that the teachers were not practiced it properly.

\subsubsection{Teachers' Practices in Using Reading Strategies}

Another objective of this study was aimed to assess whether teachers employ reading comprehension strategies required of each phases or not in teaching reading comprehension. To this effect the research question was, do teachers' employ the basic reading comprehension strategies required of each reading phases to teach reading comprehension?. To answer this question the researcher was employed questionnaire, interview, observation and finally to cross check the observation in terms of the content the text book (observed lesson) that where they are designed to implement multiple reading strategies the content was analyzed.

In this regard, 10 strategies were used to test the extent to which teachers were applying these strategies. The one sample test score obtained from teachers $(M=3.67)$ is significantly greater than the expected mean $t$-value. This shows that teaching strategies were usually used effectively. But the mean value $(\mathrm{M}=2.50)$ obtained from students was below the expected t-value which contradicts with teachers. That is the one sample test value implies reading teaching strategies were used rarely against that of teachers which is significantly lower than expected mean $\mathrm{t}$-value. This indicates that teachers and students react differently to the practice of using effective teaching strategies, teachers positively whereas students negatively. From this on can infer that there was some inconsistency of the practices of teachers' in teaching post reading phase.

Regarding to what extent teachers were using practical strategies like asking and answering questions, 
monitoring comprehension, meta-cognition, recognizing story structure, and multiple strategies interviewees reacted differently. That is to mean the result obtained from interview also indicates that the teachers were not practiced majority of the reading strategies except asking and answering questions. So, this shows that there is some sort of gaps in teaching reading strategies.

It is indicated that teachers were used to ask questions and answering questions (rarely practiced) in every class. But they were not able to use other strategies. Similarly the data obtained from classroom observation checklists and filed notes indicate that the teachers were not practiced reading comprehension strategies to the expected level. Moreover, all the observed teachers didn't apply Meta cognition. And in applying multiple strategies teachers are teaching without applying proper strategies that enable them to teach reading comprehension as expected and scientifically accepted strategies. Contrary to these findings the content analysis indicated that the text book was designed by including different reading strategies despite teachers didn't use properly.

This finding corroborates the work of, the findings of Dereje (2013) and Mesfin (2008) also found that teachers neglected to provide reading comprehension strategy instruction except a few strategies and they failed to teach the importance of reading comprehension strategies. Moreover, Durkin (1977) indicates that acquire some general impression of what teachers do when they teach reading comprehension. The conclusion was that "not much is done that could be called reading comprehension strategies. Similar to this finding, the current study also found that the teachers' practices were not efficient and effective in terms of variability and application of the strategies in the classroom. Besides this, Reutzela et.al (2005) regarding teaching reading comprehension strategies explained that employing multiple comprehension strategies within a collaborative, interactive and engaging routine task has a significant for the improvement of students reading ability. But, in the contrary to this the result of this study indicates that the actual practice of the teachers in implementing multiple strategies in their reading class was not enough.

So, this indicates that the there is a huge gap in literature view of teaching reading comprehension strategies and the actual practice of the teachers in their reading class since the result showed that they were failed to properly implement multiple strategies.

\subsubsection{Factors that Affect Teachers' Practices of Teaching Reading Comprehension}

The last objective of this study was aimed to identify the factors that affect teachers teaching practice in reading comprehension. To achieve this objective the research question, do teachers apply reading phases properly in their actual classroom teaching? was raised. So, four factors related to students, teachers, subject content and context related were used to assess the extent these factors affected teachers teaching practice of reading comprehension. The results obtained from the instruments are discussed as follows.

One of the factors considered was students' related factors. The results obtained from teachers $(\mathrm{M}=4.19)$ is significantly greater than the expected mean t-value. This shows that students related factors were highly influences teaching of reading comprehension effectively. Similarly, the mean value $(M=3.18)$ obtained from students has a mean difference above the expected t-value. That is the one sample test value of the students related factors mean score obtained from students $(M=3.18)$ is significantly greater than expected mean t-value. This indicates both teachers and students responded as factors related to students (language problem, Being unfamiliar with the topic and unable to understand every word, Lack of confidence, motivation and interest) are highly influence to teach reading comprehension properly. The students themselves were influencing the teaching and learning in reading comprehension, but when compared with teachers' response; it is smaller nearer to average. In short, the result from questionnaire indicates that students' poor background knowledge, low motivation or interest to learn reading comprehension as well as lack of confidence affect the practices of teachers' in teaching reading comprehension. This is also sported by open ended questions.

Similarly, the interview result also indicated that students have a big problem: they were not well prepared, motivated, and willing to attend their class actively. All the participants reported that students faced difficulties because of lack of the knowledge of vocabulary and grammar, low background knowledge of the subject and their negative attitude towards reading skills are the factor which are related to students.

Regarding this factor, text comprehension requires both language knowledge (vocabulary and grammar knowledge) and recognition of key ideas (Grabe, 2004). Supporting this result, John (2005) explained that students who lack adequate vocabulary have difficulty of getting meaning from what they read, so they read less because they find reading difficult. Similar to this the current study also founds the students poor background and linguistic knowledge, low attitude towards reading comprehension and inadequate knowledge of the language affect the practice of teachers in teaching reading comprehension. In the support of this study result, Bedasa (2013) indicates that cultural and content/ topic unfamiliarity, limited vocabulary knowledge the problems impede the teachers to implement teach reading comprehension. Nunan (1998) also suggested the learners' factors as: background knowledge, motivation, confidence, linguistic competence, and cultural knowledge. Thus, the students were negatively affecting the practice of the teachers' practice of teaching reading comprehension.

Another factor which hinders the practice of teachers is factors which are sourced from teachers. The results obtained from questionnaire in relation to teachers indicated teachers mean value $(M=2.17)$ is significantly less 
than expected mean t-value. This shows that teachers related factors have low influences in teaching reading comprehension effectively. But, the mean value $(\mathrm{M}=3.11)$ obtained from students has a mean difference above the expected t-value. This indicates teachers and students responded differently for factors related to teachers. Probably it is possible to say teachers considered themselves as they were not factors to influence in teaching reading comprehension whereas students responded the reverse. Moreover, even though the teachers' were not considered themselves a factor for teaching reading comprehension the students' responded that the teachers' were not engage in all reading phases and they did not teach different reading strategies in their reading class due to lack of confidence, motivation in teaching reading comprehension, teaching experiences, and using proper teaching strategies.

Similar to this the result interview also indicates that teachers were not considered themselves they are not a factor for their proper teaching of reading comprehension. In addition to this, although most of the teachers did not express clear awareness of reading strategies, they thought that reading instruction should involve strategy training. In the filed note the result there is teachers were lecture oriented rather than using newly developed strategies and apply multiple strategies while students were passive listeners except very few participants. So, this indicates that the teachers' method which employee in the classroom was not proper.

Similar to this result obtained from the current study, Asfaw (2008) indicates that the absence of 9implementation of pre-reading, while-reading and post reading phases by teachers weaken the comprehension ability of grade 9 students. English teachers did not give the learner reading strategy training. They did not give adequate support on how to develop reading activities.

Although some teachers claim that they do such activities. In connection to this Dennis (2008), stated that the type of instruction that a student receives will also affect reading comprehension and strategies for improving reading comprehension must be taught directly by teachers. Due to this fact, EFL teachers need to be selective and analytical to choose suitable methodology which helps them to implement in their actual classroom.

Supporting this finding, McDonough and Shaw (1993), and Stern (1983) list teachers' factors that affect students' language learning. These include: attitude toward teaching the skills, beliefs about language teaching, and language teaching experiences, knowledge of subject matters, and language teaching methods. As the result obtained from teachers' questionnaire of this finding indicates that the teachers were not consider the factor for their practice but the students result was supported the scholars view.

Subject contents are also considered one of the factors. In this regard the one sample test mean score obtained from teachers $(\mathrm{M}=3.05)$ is almost equal to expected mean $\mathrm{t}$-value. Similarly, the mean value $(\mathrm{M}=3.12)$ which is almost equal to the expected $t$-value. That is the one sample test value of the subject content related factors mean score obtained from students $(\mathrm{M}=3.12)$ is nearer to expected mean $\mathrm{t}$-value. This indicates both teachers and students responded as factors related to subject content (Difficulty of vocabulary, unfamiliar topic, uninteresting topic, lengthy and detailed text, and complicated grammatical structure) moderately influence teaching reading comprehension. Moreover, in result obtained from open ended questions revealed that the content of the text book was not designed effectively by considering students cultural, and linguistic background, there is a repetition of the content that makes the students bored, and since the content was too long it push the teachers to select the content and ignore some of the strategies.

Interview result indicated that the text book has many pages to cover all the contents on time as a result they obliged to be fast rather than teaching each of the contents. And it also indicates that the contents of the text book were not designed by considering the reading phases and strategies. The teachers reported that the reading material should be interesting or at least related to the background knowledge of the students.

In relation to the text book content related factors, the result of the current studythat is consistent with the finding of Salatac and Akyel (2002) found out that the texts should be based on learners' interest and background knowledge. Concerning the extent of influence of textual factors in reading comprehension Asfaw (2008) found that lack knowhow of comprehension as the ability to comprehend academic texts impede at high extent, and textual difficulty hinders reading comprehension of students at high extent. How of poor foreign language competency and did not differentiate its impact on textual difficulty and their relationship.

Dennis (2008) also explained that a text book that is well organized and clear is called "considerate text" and text that is poorly organized and difficult to understand can be called "inconsiderate text." The more inconsiderate the text, the more work will be required of a reader to comprehend the text. And the complexity of the texts is one of the factor is influenced by the readers' strength and fluency in language and their comprehending of its applications and different meanings. But, the result obtained from interview and questionnaire indicates that the text book was not designed by considering the reading phases, strategies and it was not designed by considering the students cultural and linguistic background. Even though it the result obtained from content analysis indicates that the text book tries to consider reading phases and strategies with some gaps.

The last but not the least factor considered as a factor affecting reading comprehension was context related factors. The one sample test value for context related factors mean score obtained from teachers $(M=4.32)$ is significantly greater than expected mean $\mathrm{t}-\mathrm{value}$. Similarly, the mean value $(\mathrm{M}=3.18)$ obtained from students has 
a mean difference above the expected t-value. This indicates both teachers and students responded as factors related to contexts (Class room arrangement, large class size, time constraints to cover the lesson, and shortage of resources)are highly influence teaching reading comprehension. In the support of this result the result obtained from the open ended questions illustrates shortage of time to handle multiple reading strategies and engage the all the students in their reading class.

Interviewees responded that the classroom context highly affect students learning as well as teachers teaching practice. Numbers of students in a classroom, time allocated for a lesson, cultural backgrounds where students grew up were some of the context related factors affecting the teaching and learning in English class reading comprehension in particular. In the classroom observation-field notes result ensured that the sitting arrangement, the class size was daunting factors exist in every classrooms and the time which was given for the reading lesson is not enough and impedes the teachers don not teach all reading phases and related strategies properly. Besides to this the content analysis indicates that the reading lesson tried to incorporate reading phases and instruct the teachers to teach different reading strategies even though there is some gaps and repetition of activities.

In collaboration to the findings of the current study the work of Akinbade (2007), who found that a conducive environment is the bedrock without which learning would be impaired and not effective. Similarly, the result of the current study also indicates that the school arrangement, class size and the time give to accomplish the reading tasks. Supporting this finding, Nuttall (1982), stated that if the schools use different interested library books, qualified librarians can motivate and invite the students to read more outside the classroom. Reading skill is more of learnt and improved if the students find interested reading materials.

\section{Conclusions}

Based on the results obtained and the summary stated above, the following conclusions are drawn.

1. The reading phases (pre, while and post) that should be followed in teaching reading comprehensions were not properly practiced in secondary schools of the study area with insignificant and inconsistent differences among teachers. Most of the data collected showed that teachers were not able to apply and practice the three important phases; particularly the actual classroom observation proved that teachers were not teaching following the procedures and applying effective reading teaching strategies. Thus, teachers should take out themselves from the conventional method of teaching to scientific and modern ways of teaching unless they cannot achieve the intended objectives designed to address after teaching reading comprehension.

2. Applying proper and compatible teaching strategies that fit content of the lesson as well as in line with addressing the intended objective of the lesson is mandatory and useful. In teaching reading there are plenty of teaching methods that teachers can choose from. In this study 10 possible teaching strategies were selected in addition to strategies employed in each reading phases and results showed that most of the strategies were not used in the expected way. Teachers usually use incomplete question and answer method and providing activities now and then. In sum, strategies were poorly recognized and used by teachers in teaching reading comprehension.

3. Problems considered in this study were found serious however teachers deny themselves were not sources of problems. Factors related to students, context and teachers hampered the teaching and learning process. Subject content related was realized that averagely affect the process but the document analysis contradicts this. Except some contents analyzed most of the contents were confortable to teach following reading phases and applying effective teaching strategies. To this end teachers as well as students should look at thoroughly to ensure whether the contents included in the text are covered properly and the intended objectives are achieved.

\section{Recommendations}

Based on the results obtained, summary and conclusions madethe researcher would like to recommend the following.

1. English language is one of the subjects given in secondary schools and also used as medium of instruction to teach other subjects. It is obvious to hear and observe a number of complains form teachers, parents and students themselves regarding the skills of students in using the language effectively in other subjects as well as in English subject itself. This may arise from the problem of teaching students the language properly following scientific procedures. In this study the results showed as teachers were not able to apply the phases of teaching reading comprehension and applying tested strategies. Thus teachers should follow reading phases and related activities to ensure whether students are learning the passage or not. For this not only teachers, students should be clearly informed to follow the phases in reading passages so as to make them effective.

2. It is possible to recognize thatteachers teaching skills at least by observing 12 classes in the three secondary schools. As to the researchers' observation, teachers were using lecture method in every class where student were considered passive listeners without interaction to each other and with the teacher. 
Therefore, it is advisable to train teachers on teaching methods particularly how to teach passages. The schools, Woreda Education office, Zone Education Departments, Region Education Bureau, MoE and Universities can take training initiatives either in short term or long term training.

3. Students play the vital role to make the classroom more hot and participative. For this school supervisors should conduct frequent classroom observation to check how the teaching learning process is going on unless the presence of supervisors in schools seems wastage. Moreover, students should get awareness on how to attend their class to make them active learners, involve in cooperative activities. For this trainings in the school should be organized and provided.

4. Text book based discussion among English teachers should hold to share their experiences, knowledge and skills. Schools can do this connecting it with CPD programs. Universities can share this responsibility as one of the community service because the problem will grow to university students. Woreda Education office and other responsible bodies can organize capacity building trainings to solve the identified problems one by one rather than devoting their time on irrelevant tasks.

5. Finally, the researcher would like to suggest that many research issues are available in the school context like assessing language skills, motivating students to learn English language effectively, helping students to learn by themselves and so on. Therefore, any interested research can search and investigate scientifically to improve English language teaching and learning.

\section{References}

Akinbade, A. (2007). Free education: Why we outsmart other states in Nigeria. The Nigerian Education Times 14 (May-June): 18.

Anderson, R.C., \& Pearson, P.D. (1984). A schema-theoretic view of basic processes in reading comprehension. In P.D. Pearson, R. Barr, M.L. Kamil, \& P. Mosenthal (Eds.), Handbook of reading research (pp. 255-291). New York: Longman.

Asfaw Workalemahu Endale.(2018). Factors affecting grade 9 students English reading comprehension: The case of Debesso and Chercher Secondary Schools . Unpublished MA Thesis: Haramaya University.

Ayalew Shibeshi (2009). Secondary school teacher deployment in Ethiopia: challenges and policy options for redressing the imbalances. In: Proceedings of the 16th International Conference of Ethiopian Studies, ed. by Svein Ege, Harald Aspen, Birhanu Teferra and Shiferaw Bekele, Trondheim 2009

Aydogdu, E. (2007). EFL teachers' perceptions of foreign language teaching competences. Trakya: Trakya University press. (Unpublished Research)

Baker, J. and Westru, H. (2000). The English language teachers hand book. London: VSO continuum.

Bedasa Melese. ( 2013). Assessing the Practices of Pre-reading Activities in EFL Classrooms: The Case of Gudeyajare Secondary School in East Wollega Zone, Oromia (Unpublished MA. Thesis). Haramaya University.

Bensusan, M. (2002). On schema affects EFL reading comprehension. Journal of Research in Reading .Doi: 10.1111/1467-9817.00058 file///:/abstract.htm

Biancarosa, G., \& Snow, C. (2006). Reading Next $-A$ vision for action and research in middle and high school literacy: A report to Carnegie Corporation of New York. Washington, DC: Alliance for Excellent Education.

Brown, H. D. (2000). Principles of Language Learning and Teaching. New York: Longman.

Bursuck, W \&Damer, M. (2007).Reading instruction for student at risk or disabilities. Boston: Pearson Education. Inc.

Carrell , P.L., Pharis, B. G., \&Liberto, J. C. (1989). Meta-cognitive strategy training for ESL reading. TESOL Quarterly, 23(4), 647-678

Chall, J. (1967). Learning to Read: the Great Debate. London: McGraw-Hill

Creswell, J.W. (2014). Research design: Qualitative, quantitative and mixed method approaches (4 ${ }^{\text {th }}$ Ed.). USA, SAGE Publications.

Cronbach, L. J. (1951). Coefficient alpha and the internal structure of tests. Psychometrika, 16, 297-334 (28,307 citations in Google Scholar as of 4 /1/2016).

Dennis, D. V. (2008). Are assessment data really driving middle school reading instruction? What we can learn from one student's experience. Journal of Adolescent and Adult Literacy, 51, 578-587. Retrieved from http://dx.doi.org/10.1598/JAAL.51.7.5

Dereje Bekuma. (2013). An assessment of teachers' practice in teaching reading comprehension strategies in EFL classes: grade 9 and 10 English language teachers of Jorgo Nole and Ula Babu high schools in focus. Unpublished Ma Thesis: Jimma: Jimma University.

Dereje Wondimeneh. (2008). An investigation of students' perception of motivational techniques teachers use for reading lesson in W/Ro Kelemework Tiruneh Secondary School. Unpublished Ma Thesis.

Ethiopia Early Grade Reading Assessment (2010). Ethiopia early grade reading assessment data analytic report: Language and early learning. USAID/ Ethiopian. Retrieved From 
https://www.usaid.gov/sites/default/files/documents/1860/Ethiopia_Early_Grade_Reading_Assessment.pdf.

Gibbs, C.J. (2002). Effective teaching: exercising self-efficacy and thought control of action. Auckland University of Technology, New Zealand, Annual Conference of the British Educational Research Association Exeter England. Accessed on February 10, 2019 http://www.leeds.ac.uk/educol/documents/00002390.htm.

Grabe,W. \&Stoller,F.L.(2002). Teaching and research reading. Edinburgh Gate: Pearson Education.

Habtamu Walga Adaba (2016). Assessing factors affecting the students' reading speed and comprehension: Manasibu secondary school grade $9^{\text {th }}$ in focus: western Wallagga zone. International Journal of Language and Linguistics, 4(5): 165-182doi: 10.11648/j.ijll.20160405.12.

Hedge, T. (2003). Teaching \& learning in the language classroom. UK: OUP.

Huang, L. V., Nelson, R. B., \& Nelson, D. (2008). Increasing reading fluency through student-directed repeated reading and feedback. California School Psychologist, 13, 33-40.

Jennings, J., Caldwell, J., \& Lerner, J. (2014). Reading problems assessment and teaching strategies. Boston, MA: Pearson Education, Inc.

John, S. 2005. Effective Vocabulary Instruction. Insights on learning disabilities. 2(1): 1-10

Ko, J., Sammons, P., and Bakkum,L. (2016).Effective teaching: A review of research and evidence. Reading, Berkshire Education Development Trust. Retrieved from https:/files.eric. ed.gov/fulltext/ED546794.pdfon February 20,2019.

Kothari, C.R. (2004). Research methodology: Methods and techniques(2nd ed.). New Delhi, New Age Publishers.

Leyla T,E.L. and Almacioğlu,G. (2009). Three reading phases and their applications in the teaching of English as a foreign language in reading classes with young learners. Journal of Language and Linguistic Studies Vol.5, No.1.

Lien, H. Y. (2011). EFL learners' reading strategy use in relation to reading anxiety. Language Education in Asia,2(2), 199-212.

Marshall, C. \& Rossman, G. B. (1989).Designing qualitative research. Newbury Park, CA:

McClure, C. (2008). Creating early, engaged learners: Motivation and reading. Retrieved from: http://www.districtadministration.com/viewarticlepf.aspx?articleid=1445.

McDonough and Shaw, C. (2003). Materials and methods. A Teacher's Guide (2 ${ }^{\text {nd }}$ ed.). $\quad$ Australia. Blackwell publishing.

McNamara, C. (1999). General Guidelines for Conducting Interviews, Authenticity Consulting, LLC, Retrieved from www.managementhelp.org/evaluatn/intrview.htm

Mei-yun, Y. (1994). Teaching efficient EFL reading. Selected articles from the English teaching forum anthology 1989-1993.

Mendida Fufa (1988). A comparison of the reading level of Bahir Dar teachers' college freshman students with the reading levels expected of them. MA Thesis: Addis Ababa University.

Mesfin Derash . (2008). The practices of Teaching Reading in English at First Cycle Primary Schools (MA Thesis). Addis Ababa: Addis Ababa University Press.

Ministry of Education (MoE). (2016). Education Sector Development Program: Program Action Plan. Addis Ababa, Ethiopia.

Ministry of Education (MoE).(1994). Education and Training Policy. Addis Ababa: Saint George Printing Press.

Ministry of Education (MoE).(2017). Education Sector Road-map (unpublished document).

MoE.(2003). English for Ethiopia: Student textbook grade 9. Federal Democratic Republic of Ethiopia, Ministry of Education. Addis Ababa.

Nuttall, C.(1996). Teaching Reading skills in a Foreign Language. London: Heineman.

Palani, K. K. (2012). Promoting reading habits and creating literate society. International Refereed Research Journal. Retrieved from www.researchersworld.com. Vol. III, Issue 2(1), April 2012 [90]

Phillips, J.K. (1985). Proficiency-based instruction in reading: A teacher education module. Sample materials-Chinese (Mandarin), English as a second language (beginning and advanced), French, German, Japanese, Russian, Spanish, and Thai. U.S. Department of Education Office of International Studies, \#G008402271.

Professional Development Service for Teachers (PDST) (n.d). The reading process. Retrieved from https://pdst.ie/sites/default/files/15.\%20The\%20Reading\%20Process.pdf

Salataci, R. \& Akyel, A. (2002). Possible effects of strategy instruction on L1 and L2 reading. Reading in a foreign language, 14/1. Retrieved on March 2019 from http://nflrc.hawaii.edu/rfl/April2002/salataci/salataci.html

Shewa, B. (2017). An assessment on factors affecting student -teachers' inferential understanding in reading comprehension practice: The case of Gilgelbelescollege of teacher education, Benishangul Gumuz region. Internationaljournal of social science and management, 4(2): 148-153, DOI: 10.3126/ijssm.v4i2.17168

Stronge, J.H., Tucker, P.D. \&Hindman, J.L. (2004).Handbook For Qualities of Effective Teachers. Association for supervision and curriculum development, Alexandria, VA, USA.

Teshome Eshetie .(2016). English language teachers' implementation of reading lessons in the new course book: The case of grade nine. Unpublished MA thesis: Arbaminch University 
Uygun ,S.(2013). How to Become an Effective English Language Teacher. Yeditepe University Journal of Educational and Social Research. MCSER Publishing, Rome-Italy Vol.3 No.7.

Walker,R.J. (2013).Characteristics of an Effective Teacher. Lulu Publishing

Wallace, C. (1993). Reading. Oxford: oxford University Press.

Weaver, C. (1990). Understanding Whole language: From Principles to Practice. Portsmouth NH: Heinemann. Williams, E.(1984). Reading in the Language Class Room. London Macmillan publishers Ltd. 